\title{
To the Memory of R. Freivalds
}

\author{
Efim KINBER \\ Computer Science Department, Sacred Heart University \\ 5151 Park Avenue, Fairfield, CT, USA \\ kinbereesacredheart.edu
}

\begin{abstract}
The paper contains author's memories of his mentor and teacher R. M. Freivalds.
I met Rūsinš Freivalds for the first time in September of 1970, and this meeting defined my life in many different ways. At that time I was a fifth year student in the mathematics division of the University of Latvia and was looking for a topic and an advisor for my diploma thesis. My original idea was to write a thesis in the field of Lie Algebras, where I had been doing some research under the guidance of one of the faculty. However, algebraists, led by an outstanding mathematician B. I. Plotkin, were gradually forced out of the University, after one of the star students in his group, I. Rips, attempted a public self-immolation, protesting Soviet invasion to Czechoslovakia in 1968, and, thus, I had to change direction, and did not know what I would do.
\end{abstract}

However, in the first days of September, I was summoned to a meeting by the Dean of the Faculty of Physics and Mathematics A. Liepa. This meeting decided my fate. Prof. Liepa told me that Jānis Bārzdiňš, his former classmate, returned from Moscow (where he was working on his doctoral dissertation under the guidance of A. N. Kolmogorov) and would be forming a new division in the University Computing Center. Prof. Liepa suggested that he could recommend me to J. Bārzdinš to join his group. Frankly, I was scared - I knew nothing about computer science at the time, except for having taken a couple of courses in programming. But Prof. Liepa told me: "Trust me: computer science is the future, and J. Bārzdiňs is one of not so many people in this whole country (he meant the Soviet Union) who can guide you into this new exciting field", and that was it. He arranged my meeting with J. Bārzdinšs, but there was another man present at the meeting, Rūsiņš Freivalds. J. Bārzdiņš told me that he himself was too busy at the moment to guide my diploma thesis, and suggested working with Rūsinšs, who just returned from Novosibirsk, where he was completing his Candidate of Science dissertation (Ph.D.) under the guidance of B. A. Trakhtenbrot. Then J. Bārzdiņš left, and we started our very first long conversation with Rūsinșs. In about three hours, he taught me the basics of Turing machines, computability, Church-Turing thesis, introduced me to the concept of so-called $(\mathrm{m}, \mathrm{n})$-computation, and explained to me the results recently 
obtained on (m,n)-computation by Trakhtenbrot (1964). One (m,n)-computing device can compute many recursive functions with frequency $\mathrm{m} / \mathrm{n}$ of correct answers. Rūsiņš suggested to me to find out if there is a $(m, n)$-computing device that is guaranteed to compute just one recursive function.

I was completely overwhelmed, to say the least... Rūsiņš saw it on my face, but he smiled and said: "Don't worry, one thing at a time, I am going to give you few relatively simple algorithmic tasks - solve them first, and then get to the $(m, n)$-computation problem. And, at any moment, if you have questions, try to reach me for help". I went home in complete despair. One of the reasons for my despair was that, as Rūsiņš told me, there were no books available on the theory of computing at that time (there existed the book "Theory of Recursive Functions and Effective Computability" by H. Rogers, but it was in English, and my knowledge of English was very poor at that time, and we did not know if the book was even available in any library in the Soviet Union, let alone Latvia), and Rūsiņš could offer me copies of very few articles that could be considered as foundational (he brought these copies from Novosibirsk and loaned them to me, as copying at the university was not possible at that time at all). So, I could count practically only on conversations with Rūsinsš. And he guided me to a miracle: by the beginning of November, I was able to grasp the key ideas of computability to such extent that I could get the aforementioned $(m, n)$-computation problem solved. Rūsinšs did not hide his excitement and when he went to Novosibirsk in December, he reported this result on the Trakhtenbrot's seminar. Forty six years have passed, and I still cannot believe that this happened... I know that it could not have happened if anybody but Rūsinšs was my teacher and mentor.

I never had a chance to take any courses with Rūsinšs (I think he actually started teaching only in the 80s), yet there were many other ways he taught me theoretical computer science and some aspects of mathematics. In particular, over the years, he recommended that I read a large number of articles (and few books that would be available on the subject in the USSR at that time - in particular, the book on computational complexity by B. A. Trakhtenbrot). We then discussed some of the books and articles together. A great source of education was the theory research seminar, led originally by J. Bārzdinšs, and then taken over by R. Freivalds. In these seminars participants learned and discussed cutting edge results from both members and guest speakers. An invaluable help was editing multiple versions of my first articles by R. Freivalds and J. Bārzdinšs. I recall that they accepted only the $5^{\text {th }}$ or $6^{\text {th }}$ version of my first article (to be presented to A. N. Kolmogorov for recommendation for publication in the prestigious at that time Soviet journal Dokladi Academii Nauk). They taught me how to present the ideas and results in a clear and transparent, yet logically perfect manner. But the most amazing part for me was that they edited my native Russian, even though they were not native speakers! They suggested both corrections and even different ways of expressing my ideas. In these suggestions they used more suitable and precise Russian words than I should have used, and, of course, I considered myself quite well-versed in my native language! I once discussed this issue with Rūsiņš, and he humbly attributed his 
knowledge of this part of the Russian language and such a skillful use of it to the years he spent in Novosibirsk under the guidance of B. A. Trakhtenbrot. But he neglected to mention his general insatiable interest in different languages, cultures, history, and literature, including Russian. On a couple of occasions he showed me his home library which was constantly growing - and I was astonished by the breadth and depth of his various interests in literature, philosophy, history, and sciences. Our mutual sole regret was that he completely lacked any interest in classical music - or any music, at least at that time.

One of Rūsiņšs's invaluable qualities was his constant interest to different parts of mathematics and his ability to relate his new knowledge to the problems he was working on (often with students or other colleagues). Sometimes, while studying mathematics, he was also getting inspiration for formulating new tasks in the areas of theoretical computer science he was working at the time. For example, while studying measure theory and probability theory, he came across Borel-Cantelli Lemma. It gave him an inspiration for studying probabilistic inductive inference with limited (long-term) memory. He attracted my attention to this lemma and explained his vision of how it could relate to the topic in question. We successfully applied it to obtain quite non-trivial results in this area (published in the Journal of ACM, cf. (Freivalds et al., 1995)).

I would be a remiss if I did not mention yet another aspect of his mentorship that was particularly important to me. As I already mentioned, my native language is Russian, and in the Soviet Latvia, with Latvian and Russian-speaking communities being quite separated, I happened to have a little exposure to Latvian language before meeting Rūsinšs: I graduated from Russian-speaking school, all courses in the university that I took were in Russian, and the quality of teaching Latvian in Russian schools was very poor. Suddenly, I became a part of predominantly Latvian-speaking group. I was eager to learn Latvian and gladly immersed myself in this environment, but since all my Latvian colleagues spoke Russian much better than I spoke Latvian, some of them, being forthcoming, continued to talk to me in Russian for many years, which, of course, was not helping me to learn the language. Yet Rūsinšs, in our conversations, which started almost exclusively in Russian, was gradually adding more and more of Latvian, sometimes suggesting a new word or expression to me, and I am indebted primarily to him for being able to speak Latvian quite fluently in few years.

Yet another aspect of education, particularly important for me (although, the reader would, perhaps, disagree with the use of the word "education" for this area of human experience, upon learning what it was), that I received from Rūsiņš, was learning how to navigate the intricate "rules" established by Soviet authorities for Jewish scientists. I always wondered how Rūsinš, not being Jewish himself, learned these "rules" perhaps, while working with B. A. Trakhtenbrot, who was a Jew (he later emigrated to Israel) and his group that had several Jewish members.

The story of defense of my dissertation was particularly illuminating. In the beginning of 1974, my dissertation was practically ready, and several decisions needed to be made: 
where to defend it (Latvian University did not have the right to grant degrees of this level in mathematics or computer science at that time); who the two opponents would be; what would be so-called "leading organization" (a scientific structure that, presumably, was the leading authority in the Soviet Union on the subject of a dissertation).

As the topic of my dissertation was (m,n)-computation, it would be natural to ask B. A. Trakhtenbrot to serve as the first opponent, as he was the founder of this whole field of research. Upon the start of our discussion of these issues with Rūsiņš, he invited me for a walk. We sometimes talked with him about politically sensitive issues in our offices (perhaps, a bit carelessly), but this time he felt that what he was to tell me should not be told within the walls of our building. While walking along the beautiful streets of downtown Riga, he explained to me that B. A. Trakhtenbrot could not be my first opponent, as it would violate an unwritten Soviet "rule": only one individual among the defendant and two opponents could be Jewish. Since I was Jewish, neither of my opponents could obviously also be Jewish. Moreover, he said, it would not be an easy task to find an institution where to defend the dissertation, as well as opponents for a Jewish scientist. Forty two years have passed, but I still vividly remember utter disgust on his face, when he was telling me this story. I was not particularly surprised. After a bitter laugh I asked him if he had an idea how to navigate all this. It turned out, he already had a plan - and how carefully crafted this plan was! - B. A. Trakhtenbrot would represent the "leading organization" (Institute of Mathematics of the Siberian Branch of the Soviet Academy of Sciences) - thus, "dissipating" his Jewishness - I would be defending my dissertation in the Leningrad Division of the Steklov Institute of Mathematics - where a group of mathematicians working in the area of mathematical logic and computer science, led by N. A. Shanin, in defiance of the Soviet state antisemitism and restrictions on academic freedoms, would be rather sympathetic to a Jewish defendant (not every scientist in the Soviet Union was, including the Director of the Steklov Institute of Mathematics, I. M. Vinogradov) - and my opponents would be a member of this group (A. O. Slissenko) and Prof. A. V. Gladkii. Rūsinšs warned me that A. V. Gladkii was a prominent dissident, an acquaintance of A. I. Solzhenitsyn. Potentially, it could cause some problems for the prospects of my dissertation. However, in his opinion, to have a prominent dissident for an opponent would be a "lesser evil" than violating the said "rule". The plan worked beautifully (with Rūsiņš arranging all initial negotiations), and I am still in awe of his thoughtfulness and vision, without which my dissertation would not stand a chance to be defended in the Soviet Union.

I defended my dissertation in 1975, but Rūsiņš continued to mentor me for many years. During that time he advised and helped me with the choice of research topics and with many other career decisions. In particular, in 1984, he convinced me to apply for a Soviet Ministry of Education 10-month fellowship in Finland (under the guidance of A. Salomaa). I was skeptical - after all, he himself once explained to me that being a Jewish and not a member of the Communist Party would disqualify me for this kind of fellowships. Yet, his ability to discern cracks in the Soviet "management" of science scored another win for me - he hinted to me (being reluctant to express this directly) 
that, at that moment, ethnic Latvians were running the business of approving applications for the fellowship in question, and he suspected that they would be brave enough not to follow the "standard" Soviet science "management rules", and right he was - my application was ultimately approved. When I came to the Ministry of Education in Moscow for an "orientation", I was the sole Jewish scientist going to a "capitalist" country, to the disbelief of all other colleagues in my group.

Over the years, we had many conversations with Rūsiņš, touching different political issues. By no means was Rūsinsš a dissident, of the kind A. D. Sakharov, or, say, A. V. Gladkii were. He definitely was no fan of the Soviet system, especially its suppression of freedom of expression and academic freedoms. However, he usually tried to avoid direct confrontation with the system, wherever it was possible, having a greater goal of pursuing his research and developing Latvian school of theoretical computer science. He even joined the Communist Party - in particular, in order to get more chances to travel abroad. Yet, sometimes, he would make quite risky decisions, defying the system that, if unraveled, could jeopardize his career and, perhaps, his entire life. For example, surprisingly, while being admitted to the Communist Party, he never joined the Youth Communist Organization, which was nearly a must for everyone who wanted to be admitted to a university at those times. He himself sometimes wondered how he was admitted to the university. (My hypothesis now is that, since many Latvians, Estonians, Lithuanians defied Youth Communist Organization, universities had no choice but to admit the best youths, even if they were not members of the Youth Communist Organization).

One story illustrating his defiance of the System (which I also gladly, and, perhaps, equally carelessly, joined) was as follows (to me, this story vividly reflects and illuminates the general decline of the Soviet system). In the mid-70 ${ }^{\text {th }}$, we decided to try sending our papers to conferences and journals abroad. Of course, articles would be written in English. However, for each paper in English, one had to get a permission from so-called "First Division" of the University (which was just a unit of KGB, Committee for State Security of the Soviet Union), and, in order to get it, one had to submit to the said "Division" a full translation of the paper in Russian, along with the actual English text. Formally, the officer in the "Division" was supposed to check that the article did not have any "anti-Soviet" content, and Russian translation was considered to be easier to look for such possible "transgressions". Translating to Russian was a quite tedious and useless job (which, mostly, was shouldered by me), and once Rūsinsš - perhaps, getting tired of my "whining" - suggested to me reusing the Russian translation of an older - completely different - paper, replacing just the title and the front page. He suspected that the KGB officer in charge would not know English, and the whole process was for him just a formality. Of course, we took a huge risk. I can't even fathom what would have happened to us if it did not work out, but it did. We got the approval for our paper, and since then we all were using one and the same Russian text, just changing the front page. The funny (and, perhaps, somewhat dangerous for us) thing was that, of course, the size of the Russian "translation" was the same for all English papers we were submitting along, and the officer once expressed to us his astonishment that, no 
matter how long or short an English text is, the Russian text has the same size. What kind of language is this English, he once enquired of Rūsinšs and me. The climax of this story happened when a colleague from the Biology department had to quickly submit an English paper to a conference and had no time to translate it to Russian. He heard of our Russian "template" paper and came to us to borrow it. Our arguments that all our papers at least were in the field of mathematics, and his was in biology, were in vain, we gave up, and he brought our "template", along with his biological paper, to the "Division". Rūsinšs and I held our breath for few days... but it worked.

Over the years, Rūsinšs and I collaborated (sometimes, also with C. Smith or R. Wiehagen) on 18 joint papers (primarily in the area of inductive inference). None of them would have been written without his knowledge, vision, and creativity.

I am finishing my short, and, by far, incomplete account of memories of dear Rūsiņš. I wish every scientist in the world to leave such dear memories in the hearts of his/her colleagues, students, and friends, as Rūsiņš left. Forever with us, dear Rūsiņš!

\section{Acknowledgements}

I am grateful to R. McCloud and D. Taimina for a number of suggestions that greatly improved the style of the paper.

\section{References}

Freivalds, R., Kinber, E., Smith, C. (1995). On the impact of forgetting in learning machines. Journal of the ACM, V. 42, No. 6, pp. 1148-1168.

Trakhtenbrot, B. (1964). On the frequency of computation of functions. Algebra i Logika, V. 2, pp. $25-32$.

Received September 14, 2016, accepted October 26, 2016 